\title{
Calcium stable isotopes of Tonga and Mariana arc lavas: Implications for slab fluid-mediated carbonate transfer in cold subduction zones
}

\author{
XIA WANG ${ }^{1}$, ZAICONG WANG ${ }^{1}$, YONGSHENG LIU ${ }^{1}$, \\ JUNG-WOO PARK ${ }^{2}$, JONGUK KIM ${ }^{3}$, MING LI ${ }^{4}$ AND \\ ZONGQI ZOU ${ }^{1}$ \\ ${ }^{1}$ China University of Geosciences (Wuhan) \\ ${ }^{2}$ Seoul National University \\ ${ }^{3}$ Korea Institute of Ocean Science and Technology \\ ${ }^{4}$ State Key Laboratory of Geological Processes and Mineral \\ Resources, China University of Geosciences \\ Presenting Author: wangxia.1@outlook.com
}

Carbonation of oceanic lithosphere occurs widely during seawater alteration, and subducted carbonated oceanic lithosphere may play a key role in carbon recycling in subduction zones. Here we investigate the $\mathrm{Ca}$ isotopic composition of arc lavas from the Tonga rear arc and Mariana arc, western Pacific, to explore the effect of fluid-mediated carbonate transfer in subduction zones. Fresh basalts $(0.84 \pm 0.01 \%$, $2 \mathrm{sd}, \mathrm{n}=3)$ and dacites $(0.84 \pm 0.10 \%, 2 \mathrm{sd}, \mathrm{n}=9)$ from the Tonga rear arc show indistinguishable $\delta^{44 / 40} \mathrm{Ca}$, reflecting negligible $\mathrm{Ca}$ isotopic fractionation during differentiation of hydrous arc magmas. More importantly, arc lavas from both the Tonga rear arc $(0.84 \pm$ $0.09 \%, 2 \mathrm{sd}, \mathrm{n}=12)$ and Mariana $\operatorname{arc}(0.79 \pm 0.12 \%$, $2 \mathrm{sd}, \mathrm{n}=9)$ display MORB-like $\delta^{44 / 40} \mathrm{Ca}$ values. The MORB-like $\delta^{44 / 40} \mathrm{Ca}$ of arc lavas indicates that the carbonates released from altered oceanic lithosphere (AOL) do not significantly modify the $\mathrm{Ca}$ isotopic composition of the mantle wedge, although extensive volcanic $\mathrm{CO}_{2}$ degassing at both arcs suggests that slab fluids might introduce abundant carbonate into the depleted mantle wedge. These results could be attributed to a limited Ca budget in the slab fluids added to the mantle wedge and/or homogeneization effect of variable $\delta^{44 / 40} \mathrm{Ca}$ for the slab fluids. At cold subduction zones, a fraction of carbonates from the AOL may survive during slab dehydration and recycle into the deep mantle. 